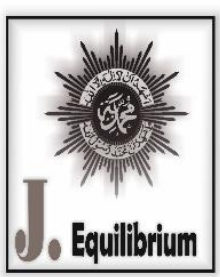

\title{
Manajemen Pendidikan Islam dalam Menjaga Kualitas Pembelajaran di Tengah Pendemi Covid-19
}

\author{
Syahrul Ramadhan \\ Prodi Pendidikan Sosiologi, UIN Sunan Kalijaga Yogyakarta \\ Email : syahrul7394ramadhan@gmail.com
}

\begin{abstract}
This article wants to discuss how the management of Islamic education in maintaining the quality of learning in the midst of the Covid-19 pandemic. Islamic education during a pandemic must have the right management because Islamic education is not only concerned with intellectual issues but also about spiritual issues. The purpose of Islamic education is a starting ethic, so automatically the management of Islamic education must be correct. During the pandemic, the management carried out by the Ministry of Religion and its staff launched a planning, management and supervision by means of online learning. Implementers of each school along with supervision and parents and peers are the most core supervisors in Islamic education. By using qualitative methods based on previous research and several books as primary and secondary sources, it is hoped that it can make a big contribution to Islamic education and scientifically there is an image of a new file taste for future scholarship.
\end{abstract}

Keywords : Islamic Education, Covid-19, Management, Schools, and Parents.

\begin{abstract}
Abstrak. Artikel ini ingin membahas bagaimana manajemen pendidikan Islam dalam menajaga mutu pembelajaran di tengah pandemi Covid-19. Pendidikan Islam di masa pandemi harus memiliki manajemen yang pas karena pendidikan Islam bukan hanya mementingkan masalah intelektual tapi juga mengenai masalah spiritual. Tujuan dari pendidikan Islam adadalah ahlak yang mulai, maka secara otomatis manajemen dari pendidikan Islam harus tepat. Di masa pandemi, manajemen yang dilakukan oleh Kementrian Agama beserta jajaranya mencanangkan suatu perencanaan, pengelolaan dan pengewasaan dengan cara pemebajaran online. Pelaksananya sekolah masing-masing beserta pengawasan dan orang tua serta teman sejawat menjadi pengawas yang paling inti dalam pendidikan Islam. dengan menggunakan metode kualitatif berdasarkan penelitian terdahulu dan beberapa buku sebagai sumber primer dan sekuder diharapkan bisa memberikan sumbangan besar terhadapa pendidikan Islam dan secara keilmuan ada citra rasa file new bagi keilmuan yang akan datang.
\end{abstract}

Kata Kunci : Pendidikan Islam, Covid-19, Manajemen, Sekolah, dan Orang Tua.

\section{PENDAHULUAN}

Pandemi Covid-19 yang menjalar di seluruh dunia terlebih di Indonesia mengakibatkan semua sektor yang ada di dalam pemerintahan harus berhenti sejenak dan memikirkan solusi terbaiknya supaya semua sektor tetap berjalan sebagaimana mestinya. Pendidikan salah satu sektor terpenting dalam pemerintahan, pendidikan menjadi pusat perhatian, terutama dalam kondisi Covid-19 yang disedang di alami oleh negara Indonesia. Seluruh elemen pendidikan, mulai dari Kementrian Pendidikan dan Kebudayaan dan Kementrian Agama Republik Indonesia yang mengelola pendidikan dari Tingkat Dasar hingga pendidikan Tinggi. Kedua elemen ini berupaya dengan keras agar pendidikan tetap berjalan dan memiliki mutu yang tinggi di tengah Pandemi Covid-19. Upaya-upaya keras terus digalakan oleh Kementerian Agama dan Kementerian Pendidikan dan Kebudayaan diantaranya dengan mengubah pola belajar yang tadinya dilaksanakan di satuan pendidikan, diubah menjadi belajar di rumah, belajar dengan menggunakan sistem daring atau belajar jarak jauh 
didampingin oleh orang tua. Solusi ini menjadi solusi yang paling efektif untuk saat ini, walaupun terdapat kekurangan itu hal yang wajar karena kita semua sedang menghadapi era New-Normal. Pembelajaran menjadi hal yang sangat penting dalam kegiatan pendidikan. Memudahkan kegiatan belajar bagi para siswa adalah tugas wajib dan mulia bagi seorang guru. Untuk itu guru tidak hanya dituntut piawai dalam menyampaikan suatu materi, tetapi guru juga dituntut untuk memanjamen pembelajaran, baik yang bersifat di dalam ruang kelas atau di luar ruang kelas. Guru harus mampu memilih materi dan metode yang sesuai dan pas sesuai dengan kompleksitas materi dan karakter peserta didik.(Saifulloh dan Darwis 2020) Sehingga metode dan pendekatan yang diterapkan sesuai dengan perkembang peserta didik, karena kita tau bahwa peserta didik bukanlah objek maliankan subjek dalam kegiatan belajar.

Sebagai generasi penerus bangsa, peserta didik diharapkan mampu mengoptimalkan segenap potensi fitrahnya untuk melakukan revolusioner bagi kemjuan bangsa ke depan. Oleh sebab itu pendidikan bukan bertujuan untuk mengembangkan pontensi intelektualitas dan keterampilan peserta didik dalam setiap proses pembelajaran, melainkan juga harus mampu menanamkan nilainilai etika dan moral yang baik dalam mengahadapi masa depan yang semakin kompleks. Untuk itu, guru harus memiliki manajemen yang baik terutama ketika berkaitan dengan pendidikan Islam. Manajemen yang harus dilakukan adalah manajemen pendidikan Islam yang sesuai dengan Pesan Islam yang ada di dalam al-Quran dan Sunnah. Dengan pengolahan manajemen yang baru dalam pendidikan Islam di bawah Kementrian Agama diharapkan bisa menghasilkan generasi yang unggul. Unggul bukan hanya ranah di intelektual dan pengetahaun tetapi juga unggul di ranah religius dan moral.

\section{METODE PENELITIAN}

Penelitian ini adalah penelitian kualitatif dengan menggunakan metode library research. Yang memanfaatkan tulisan-tulisan sebelumnya baik berupa buku, jurnal, dan artikel yang kemudian diolah dengan baik untuk menemukan pengetahuan baru supaya berguna bagi kalangan akademisi maupun kalangan masyarakat awam.(M. Iqbal Hasan 2002)

\section{HASIL PENELITIAN DAN PEMBAHASAN}

\section{A. Perkembangan Covid-19}

Covid-19 merupakan jenis terbaru yang telah menyita perhatian seluruh dunia, hampir delapan bulan virus ini sampai sekarang belum berhenti dan dampaknya sangat begitu luas. Tidak sedikit korban yang menjadi wabah terbaru ini. Bahkan hampri setiap hari virus ini memakan korban dan korbannya tidak memandang usia, tidak memandang kedudukan, dan tidak memandang jenis ras. Bahkan perkemabnag kasus dan penangan virus Corona ini terus terjadi di berbagai negara dunia. Berebagai upaya terus dilakukan untuk menekan laju perkembang virus ini, akan tetapi upaya yang dilakukan belum menampakan hasilnya.(Subhi 2020). Dengan memperhatikan kasus yang terjadi di dunia, Indonesia dengan jumlah positif dan meningga tidak bisa dipandang remeh. Pasalnya, dengan seacuhan masyarakat Indonesia dengan virus ini membuat pemerintah merasa kewalahan menghentikan laju perkembangan virus Covid-19.

Berbagai macam upaya dilakukan oleh pihak pemerintah dalam menghnetikan laju penularan virus baru ini, mulai dari PSBB, karantina mandiri, penerapan protokol kesehatan, dan kerja di rumah sendiri.(Harahap, Harahap, dan Harahap 2020). Penyakit baru ini sampai sekarang belum diketahui secara pasti penyebabnya, karena masih banyak asumsi-asumsi yang bertebaran di masyarakat mengenai perkembangan virus ini. Kita tau bahwa virus ini sangatlah berbahaya, sangat mudah menular terhadap sesama manusia. Penulran virus ini terjadi karena adanya kontak antar manusia terlalu dekat yang mana salah satu individu sudah terinfeksi, dan tanpa disadari mengelurakan cairan dari batuk dan bersin.(Purandina dan Winaya 2020) Pertahanan virus ini sangatlah kuat, ia mampu bertahan selama tiga hari dengan plastic atau stenliss dan bahkan dalam aerosul sekalipun. Wabah covid-19 ini adalah penyakit yang menular dengan membahayakan nyawa seyiap insan. Wabah yang sampai saat ini belum diketahui kapan berakhirnya dan menggunakan metode seperti cara yang 
ampuh dalam meberantasnya. Wabah ini masuk ke Indonesia pada pertengahan maret 2020. Dampak yang terjadi di Indoensia selain pada sektor perekonomian juga berdampak pada sektor pendidkan. Pemerintah dengan tegas dan sigap mengelurakan larangan untuk melakukan tatao muka dalam proses belajar mengajar, itu adalah salah satu cara mencegah penularan virus Covid19.(Anshori 2020). Dampak pandemi terhadap pendidikan mengakibatkan dilema tersendiri bagi guru dan murid. Karena seperti yang kita ketaui dengan sistem daring yang ditetapkan oleh pemerintah tidak semua guru pandai dalam mengopersikan arti, serta tidak semua murid memilki alat telekomunikasi atau gedget yang canggih untuk melakukan proses belajar mengajar dalam kondisi daring. Tapi karena pandemi semua orang diharuskan melek teknologi agar dapat memberikan pembelajaran yang kreatif untuk diberikan kepada siswanya. Ini juga salah satu tujuan dari pendidikan Islam untuk bisa menguasai teknologi dan sains.

\section{B. Pendidikan Islam}

Pendidikan Islam yang kita ketahui secara familiar memiliki dua makna secara terminologi yakni; Pertama, pendidikna tentang Islam. Kedua, pendidikan menurut Islam. terminologi pertama lebih memandang Islam sebagai subjec matter dalam pendidikan, sedangkan term yang kedua lebih menempatkan Islam sebagai persepktif dalam Pendidikan Islam. term yang kedua dipilih sebagai term dalam pembahasan kali ini. Karena masyarakat harus mengetahui bagaimana Pendidikan Islam dari kacamatan Islam. Pendidikan Islam diartikan sebagai proses pengarahan perkembangan manusia, pada sisi jasamani, akal, bahasa, tingkah lauk, dan kehidupan sosial keagamaan yang diarahkan pada kebaikan menuju kesempurnaan.(Roqib 2009) Dengan melihat defenisi yang dituliskan oelh Muhammad Hamid An-Nashir ini kita bisa mengtahui bahwa pendidikan Islam bukan saja mengarahkan manusia untuk menjadi orang yang bisa mengetahui ilmu pengetahuan, tetapi disitu juga ditekankan aspek religiusitas dan kearifan dalam pendidikan Islam.

Secara jujur, partek dilapangan pendidikan Islam yang terjadi selama ini adalah bentuk pendidikan yang berorientasi pada materi, kurikulum, metode bagaimana seorang guru menyampaikan materi Pendidikan Islam kepada anak didik. Seolah-olah pendidikan ini dipahami dengan pengertian pertama, secara otomatis yang terjadi hanya sebatas pengalihan nilai-nilai Islam dari genrasi sebelumnya ke generasi yang muncul belakangan tanpa menciptakan mereka untuk berpikir progresif dan kreatif. (Priatmoko 2018)

Sebaliknya bila pendidikan Islam dipahami sebagai konsep yang kedua, maka secara otoamtis tidak akan memandang Islam sebagai perangkat nilai yang merupakan bagian dari sistem pendidikan, melainkan memandang pendidikan sebagai sistem proses yang menjaid bagian dari sistem kehidupan Islam. secara pasti, Islam bukanlah suatu mata pelajaran yang harus ditransfer dari guru ke murid, melainkan Islam sebagai suatu ruh dari pendidikan itu sendiri. Ketika demikian, maka Islam memiliki konsep-konsep tentang pendidikan. Maka, pendidikn Islam merupakan suatu usaha orang dewasa Muslim yang bertakwa secara sadar mengarahkan dan membimbing pertumbuhan serta perkembangan fitrah anak didik melaui ajaran-ajaran islam ke arah titik yang paling maksimal pertumuhan dan perkembangannya.(Arifin 1996) Sacara teoritis pendidikan diartikan sebagai opvoeding kepada jiwa anak didik sehingga mendapatkan kepuasan rohaniah. Secara pasti bila pendidikan ingin dairahkan kepada pertumbuhan sesuai dengan ajaran yang ada di agama Islam maka harus berproses melalui sistem pendiikan Islam baik melalui kelmabgaan maupun melalui ekstrakulikuler. Karena pendidikan Islam haruslah

\section{Manajemen Pendidikan Islam}

Dengan carut marutnya sistem pendidikan Islam yang di Indonesia, dan ketidak percayaan masyarakt terhadap pendidikan kit, ini harus ada revitaliasasi manajemen yang sesuai dengan kebutuhan masyarakat Indonesia sesuai dengan perkembangan zaman. Manajemen sendiri berasal dari kata to manage, sinonim dari to hand artinya menguasai, to control artinya memeriksa, to guide berarti memimpin. Dalam melihat arti kata manajemen terdapat tiga pandangan yang berbeda, pertama, dimaknai lebih umum dari pada manajemen, kedua, melihat manajemen lebih umum dari 
pada administrasi, ketiga, pandangan yang menganggap bahwa manajemen sama dengan administrasi.(Saifulloh dan Darwis 2020) Dengan pengistilahan ini dan dilihat dari fungsinya antara manajemen dan administrasi mempunya fungsi yang sama. Oleh karena itu, perbedaan manupun persamaan diantara keduanya tidak urgen dan konsisten. Dalam memahami istilah manajemen, pendekatan yang harus diaplikasikannya adalah berdasarkan pengalaman seorang pimpinan. Manajemen sebagai suatu sistem merupakan suatu proses untuk mencapai target organisasi secara maksimal dan komprehensif. Maka untuk mencapai tujuan itu perlu dilaksanakan perencanaan (planing), pengorganisasian (organizing), penyusuran persoanlia (staffing), pengarahan dan kempimpinan (learding), dan pengawasan (controling). Jadi manajeman diartikan sebagai kegaiatan seseorang dalam mengatur organisasi, lembaga atau sekolah yang bersifat manusia atau non manusia sehingga tujuannya bisa tercapai secara efektif.(Kahfi dan Kasanova 2020)

Pembelajaran memiliki arti yang sangat jauh berbeda dengan belajar. Pembelajaran merupakan kegaiatn belajar yang fasilitasi oleh guru untuk mengembang aspek kognitif yang dapat meningkatkan daya pikir murid, serta dapat eningkatkan daya dalam mengelola pengetahuan baru. Pemeblajarn muncul ditengah proses belajar mengajar, apa lagi dengan situasi di masa pandemi pembalajarn berjalan tidkak sebagaimana mestinya harus beradaptasi dengan lingkungan. Ketika melihat pembelajaran yang bernafaskan Islam, pendidikan Islam misalnya pendidikan memiliki arti usaha sadar dan terencana untuj mewujudkan suasan belajar dan proses pembelajaran agar peserta didik secara aktif mengembangkan pontensi dirinya melalui kekuatan spriritual keagamaan, pengendalian diri, kepribadian, kecerdasan, ahlak mulia, serta keterampilan yang diperlukan dirinya, masyaraktnya, bangsa dan negara. Pendidikan bukan hanya bagi kepentingan diri melainkan pendidikan berpengaruh bagi sekelilingnya terlebih pendidikan Islam yang fungsinya sangat dibutuhkan di kalangan masyarakat secara luas. Manajemen pendidikan Islam merupakan suatu rangkaia kegiatan merencanakan, mengorganisasikan, memotivasi, mengawasi, dan mengembangkan segala upaya di dalam mengatur dan mendayagunakan sumber daya manusia, sarana dan prasarana untuk encapi tujuan lembaga pendidikan Islam yang didasarkan pada nilai-nilai Islam.(Purnomo 2020) atau dengan istilah yang lain manajemen pendidikan Islam adalah suatu penerapan berbagai fungsi manajemen dalam mengelola organisasi atau lembaga pendidikan Islam berdasarkan pada nilai-nilai Islam. Manajemen pendidikan lebih bersifat umum untuk semua aktivitas pendidikan, sedangkan manajemen pendidikan Islam lebih khusus lagi mengarah pada manajemen yang diterapkan dalam pengembagan pendidikan Islam. sudah barang tentu segala aturan yang diterapkan untuk mengelola pendidikan Islam sesuai dengan nilai-nilai ajaran Islam yang ada di dalam al-Quran dan Sunnah. Dalam hal ini Allah Swt mencitai perbuatan-perbuatan yang termanaj dengan baik. Sebagaimana dalam firman Allah Swt yang artinya:

"Sesungguhnya Allah menyukai orang yang berperang dijalan-Nya dalam barisan yang teratur seakan-akan mereka seperti suatu bangunan yang tersusun kokoh. (Qs. Ash-shaff: 4)

Ayat ini menegaskan seharusnya suatu rangkaian satu dengan yang lainnya harus kokoh harus bersinergi satu dengan yang lainnya. Harus saling menguatkan antara lapisan satu dengan lapisan yang lainnya. Apa lagi ketika berbicara masalah pendidikan yang berbasis Islam. Pendidikan harus kuat, manajemennya harus baik sesuai dengan tuntunan yang ada di dalam ajaran Islam.

\section{Manajemen Pendidikan Islam di Lingkungan Sekolah}

Dalam bukunya Zakiyah Drajat yang berjudul Pendidikan Islam dalam Keluarga dan Sekolah, ia menjelaskan bagaimana sekolah menjadi suatu lembaga pendidikan dan pengajaran secara teratur dan terencana. Sedangkan seorang guru harus dibekali dengan pengetahuan tentang anak didik serta memiliki kemampuan melaksanakan tugas pendidikan dengan baik. (Daradjat 1994) Dengan penjelasan seperti ini sekolah menjadi suatu lembaga pendidikan yang di dalamnya ada kegiatan belajar mengajar serta tempat menerima pelajaran dan memberi pelajaran. Sedangkan menurut pendidikan Islam sekolah adalah sauatu lembaga formal yang efektif untuk mengantarakan anak pada tujuan yang telah ditetapkan dalam pendidikan Islam. sekolah menjadi katalisator yang pas bagi 
mereka yang belajar di dalamnya sesuai dengan nilai-nilai yang ada di dalam al-Quran dan Sunnah. Lembaga ini harus bersikap kooperatif dengan murid dan gurunya sehingga bisa menghasilkan generesai penerus yang unggul dan berakhlakul karimah.

Tujuan ini sebangun dengan misi kerasulan, yaitu "membimbing manusia agar lebih berakhlak mulia". Akhlak mulia tersebut lebih diharapkan tercermin dari sikap setiap individu dalam hubungan dengan dengan Allah, sesama manusia, dan sesama mahluak lainnya. Tanpa penerapan ahlak yang baik di dalam sekolah, mustahil generasi penerus dapat mengimplementasikan nilai-nilai keagamaan yang termaktub dalam al-Quran dan Sunnah. Oleh karena itu manajemen pendidikan Islam dalam lingkungan sekolah menjadi begitu penting guna mendidik siswa supaya memiliki ahlak yang baik. Proses penerapan manajemen pendidikan Islam di lingkungan sekolah ini harus adanya sautu harmonisasi disemua stakeholder yang ada di dalam lingkungan sekolah yakni antara orang tua, guru dan semua yang ada di lingkungan pendidikan. Orang tua sepenuhnya menyerahkan pendidikan anak-anak kepada guru setelah anak itu berada di dalam lingkungan sekolah.

Pada masa Covid-19, sekolah harus menyedeiakan fasilitas sesuai dengan kebutuhan siswa demi menjaga mutu pendidikan yang ada di sana. Dengan cara menggunakan metode Learning Management System, virtual conference, ataupun whatsapp grup yang dibuat dan dikelola oleh pihak sekolah. Dengan kegiatan semacam demikian, materi yang dianggap sulit dan memberatkan karena sesuatu hal seperti Covid-19 materi levelnya direndahkan dengan alasan bahwa siswa tidak mungkin bisa mencerna secara baik materi yang sulit hanya dengan belajar secara virtual.(Lubis dan Yusri 2020) Karena alasan penguasaan teknologi juga menjadi penting dalam menerapkan sistem daring ini. Salah satu kendala dalam menyampaikan materi secara baik dan benar bagi lembaga pendidikan tidak bisa dipungkiri adalah penguasaan teknologi.(Al Hakim, t.t.)

Dengan cara seperti demikian, diharapkan meningkatkan minat. Motivasi, serta kemandirian belajar dan pengembangannya, terutama terakait dengan pendidikan Islam. namun sulit untuk dipungkiri bahwa kontrlonging dari pihak sekolah sangat sulit ketika menggunakan pembelajaran berbasis online, terutama terkait dengan tarbiyah.(Sari, Rifki, dan Karmila 2020) Seperti yang kita pahami bersama pendidikan Islam atau tarbiyah lebih mengedepankan rasa kasih sayang, dari pada ilmu pengetahuan. Untuk itu sangat riskan ketika pendidikan Islam menggunakan sistem seperti ini. Walaupun ini merupakan terobosan baru dalam manajemen pembelajaran yang dilakukan oleh setiap lembaga pendidikan. Di diharapkan bisa meminimlakan perbedaaan cara mengajar dan materi sehingga memberikan standar kualiats pembelajarn yang konsisten. (Vadhillah dan Utama 2020)

Namun tidak bisa dipungkiri bahwa lembaga pendidikan banyak mengalami kendala dalam menjalankan pembelajaran melalui online. Di samping para guru dan murid harus menguasai teknologi mereka juga harus mensuplai kebutuhan internet bagi mereka untuk keberlangsungan jalannya proses belajar. (Wasyik dan Hamid 2020) Inilah kendala terbesar yang memperlambang jallannya belajar mengajar di suatu lembaga pendidikan yang bernafaskan Islam.

\section{KESIMPULAN}

Covid-19 membuat semua sektor dalam pemerintahan harus memutar otak agar roda pemerintahan tetap berjalan sebagaimana biasanya, salah satunya sektor pendidikan. Lembaga pendidikan yang diwakili oleh Kementrian Pendidikan dan Kebudayaan dan Kementerian Agama menjadi sorotan dalam mengambil kebijkannya untuk proses pendidikan di negara kita. Pasalnya, pendidikan menjadi basis utama dalam menghasilkan generasi penerus yang unggul. Pendidikan Islam yang diwakili oleh Kementrian Agama mengambil langkah yang tepat dalam menerepkan proses pendidikan selama pandemi Covid-19 berlangsung. Pendidikan Islam yang harus menyeimbangkan antara kebutuhan spiritual dan intelektual harus memiliki manajemen yang pas sesuai dengan kebutuhan di masa pandemi ini. Langkah yang dilakukan Kementrian Agama masih bersikap dalam tataran formalitas hubungan heiraksis antar organisasi, seperti memberikan kuota, memberikan pelatihan pengajaran terhadap para guru, dan lain sebagainya. Maka sekolah sebagai rumah kedua dalam belajar untuk siswi harus pintar-pintarnya dalam mengelola manajemen pembelajaran untuk para siswanya. Salah satunya pembelajaran dilakukan secara daring dengan menggunakan WAG, GM, dan Zoom. Peran guru sebagai orang tua kedua tidak bisa memberikan 
dorongan lebih terhadap para siswa dalam proses belajar mengajar secara sepenuhnya karena harus ada faktor orang tua yang mendampingi para siswa dalam proses belajar mengajar. Orang tua dalam pendidikan Islam menjadi faktor utama dalam membina peserta didik untuk mencapai tujuan dari pendidikan Islam. orang tua harus memebrikan contoh yang baik kepada anak-anaknya supaya mereka memiliki wawasan intelekatual yang baik dan ahlak yang mulia

\section{DAFTAR PUSTAKA}

Al Hakim, STAI Luqman. t.t. "PEMASARAN LEMBAGA PENDIDIKAN MASA PANDEMI COVID-19 Faishal."

Anshori, Isa. 2020. "DAMPAK COVID-19 TERHADAP PROSES PEMBELAJARAN DI Mts Al-ASYHAR BUNGAH GRESIK." Islamic Management: Jurnal Manajemen Pendidikan Islam 3 (02): 181-99.

Arifin, H. M. 1996. Ilmu pendidikan Islam : suatu tinjauan teoritis dan praktis berdasarkan pendekatan interdisipliner. Jakarta: Bumi Aksara.

Daradjat, Zakiah. 1994. Pendidikan Islam Dalam Keluarga Dan Sekolah. Jakarta: : Ruhama.

Harahap, Ade Chita Putri, Dinda Permatasari Harahap, dan Samsul Rivai Harahap. 2020. "Analisis Tingkat Stres Akademik Pada Mahasiswa Selama Pembelajaran Jarak Jauh Dimasa Covid-19." Biblio Couns: Jurnal Kajian Konseling dan Pendidikan 3 (1): 10- 14.

Kahfi, Shofiyullahul, dan Ria Kasanova. 2020. "MANAJEMEN PONDOK PESANTREN DI MASA PANDEMI COVID-19 (Studi Pondok Pesantren Mambaul Ulum Kedungadem Bojonegoro)." Pendekar: Jurnal Pendidikan Berkarakter 3 (1): 26-30.

Lubis, Masruroh, dan Dairina Yusri. 2020. "Pembelajaran Pendidikan Agama Islam Berbasis ELearning (Studi Inovasi Pendidik MTS. PAI Medan di Tengah Wabah Covid-19)." Fitrah:

Journal of Islamic Education 1 (1): 1-18.

Pokok-pokok materi metodologi penelitian \& aplikasinya / M. Iqbal Hasan ; Editor: M.S. Khadafi dan Lolita. $2002 . \quad$ Bogor: Ghalia Indonesia. http://opac.library.um.ac.id/oaipmh/../index.php?s_data=bp_buku\&s_field=0\&mod=b\&cat=3 \&id=34567.

Priatmoko, Sigit. 2018. "Memperkuat Eksistensi Pendidikan Islam di Era 4.0." TA'LIM : Jurnal Studi Pendidikan Islam 1 (2): 221-39.

Purandina, I Putu Yoga, dan I Made Astra Winaya. 2020. "Pendidikan Karakter di Lingkungan Keluarga Selama Pembelajaran Jarak Jauh pada Masa Pandemi COVID- 19." Cetta: Jurnal IImu Pendidikan 3 (2): 270-90.

Purnomo, Singgih Aji Purnomo Singgih Aji. 2020. "Manajemen Pendidikan Islam Ditinjau Dari Tripusat Pendidikan." Alasma / Jurnal Media Informasi dan Komunikasi Ilmiah 2 (1): 43-58.

Roqib, Moh. 2009. Ilmu pendidikan Islam. Yogyakarta: LKiS Yogyakarta.

Saifulloh, Ahmad Munir, dan Mohammad Darwis. 2020. "Manajemen Pembelajaran dalam Meningkatkan Efektivitas Proses Belajar Mengajar di Masa Pandemi Covid-19." Bidayatuna:Jurnal Pendidikan Guru Mandrasah Ibtidaiyah 3 (2): 285-312.

Sari, Widya, Andi Muhammad Rifki, dan Mila Karmila. 2020. "ANALISIS KEBIJAKAN PENDIDIKAN TERKAIT IMPLEMENTASI PEMBELAJARAN JARAK JAUH PADA MASA DARURAT COVID 19." JURNAL MAPPESONA 2 (2). 
Subhi, Imam. 2020. "Urgensi Upaya Menjaga Mutu Pembelajaran di Tengah Pandemi Covid-19." Edification Journal: Pendidikan Agama Islam 3 (1): 35-56.

Vadhillah, Syukra, dan Hendri Budi Utama. 2020. "Manajemen E-Learning Mahasiswa Fakultas Tarbiyah Dan Keguruan Uin Imam Bonjol Padang Selama Masa Pandemi Covid-19." PRODUProkurasi Edukasi (Jurnal Manajemen Pendidikan Islam) 1 (2).

Wasyik, Torikhul, dan Abdulloh Hamid. 2020. "IMPLEMENTASI E-LEARNING DALAM PEMBELAJARAN ALQURAN ERA COVID-19 DI SANGGAR TAHFIDZ ENTREPRENEUR KRIAN SIDOARJO." EDUDEENA: Journal of Islamic Religious Education 4 (1). 